\title{
DEVELOPMENT OF LITHUANIAN PHYSICS IN THE SECOND HALF OF THE 20TH CENTURY: STATISTICAL ANALYSIS
}

\author{
R. Karazija ${ }^{\mathrm{a}}$, A. Momkauskaite ${ }^{\mathrm{b}}$, and R. Kivilšiené ${ }^{\mathrm{b}}$ \\ a Vilnius Pedagogical University, Studentu 39, 08106 Vilnius, Lithuania \\ E-mail: karazija@itpa.lt \\ ${ }^{\mathrm{b}}$ Institute of Theoretical Physics and Astronomy of Vilnius University, A. Goštauto 12, 01108 Vilnius, Lithuania
}

Received 19 September 2005

\begin{abstract}
Statistical regularities in the development of the Lithuanian physics in the second half of the 20th century are considered. After the extensive growth throughout the post-war period, the slowdown of a logistic character manifested itself in physics as well as in all the Lithuanian science; it occurred much earlier than the disintegration of the USSR began. After the restoration of Lithuania's independence, the physicists due to their closer contacts with the Western science sooner adapted to the essential transformation of the Lithuanian R\&D system. Though the percentage of scientists in physics did not exceed 6-7\%, their contribution according to the number of papers included into ISI database and several other indicators reached 40-50\% at the beginning of the 1990s. However, during the last decade the representatives of some other fields of the Lithuanian science have been actively integrating into the world science. The distribution of the age of physicists at the moment of conferring a $\mathrm{PhD}$ degree can be described by a lognormal function. The share of women had fluctuated and did not show the tendency to increase.
\end{abstract}

Keywords: statistical analysis, indicators of science, development of physics in Lithuania

PACS: $01.65 .+\mathrm{g}, 01.75 .+\mathrm{m}$

\section{Introduction}

The post-war period was very fruitful and important for the Lithuanian physics: its main directions were formed, the main physical institutions and centres were founded, physics took a leading position in the Lithuanian science. The history of this period is not written yet. It should relay not only on the investigation of the archival documents, memories of physicists, but on the consideration of statistical data as well. Such a scientometric investigation does not substitute the historical analysis, but can essentially supplement it, reveal some non-trivial, unexpected regularities.

In the post-war period, the official statistical yearbooks have been published in Lithuanian since 1957 $[1,2]$. They contained some general data on scientific activities. However, the information concerning particular fields of science was presented only for the period 1958-1975 (moreover, the information on both physics and mathematics was put jointly and the same academic degrees in these fields were conferred at that time). Later, such data were made secret. There is a gap in the official statistics of Lithuanian science for the period of political crisis in the USSR and the restora- tion of Lithuania's independence (1988-1989). Since 1990 the publication of the statistical yearbooks has been resumed [3], also the special bulletins "Research Activity" have been published [4]. Unfortunately, the information concerning the Lithuanian science has become even scarcer than in the Soviet period, some indicators of science have been replaced several times. As was shown in [5], the data on researchers given by the official statistics were very inaccurate (many unoccupied positions were counted, too, the staff of higher schools was considered as full-time researchers, etc.; the revised numbers were presented in [6]). Furthermore, only the summed up data on the physical, technological, and other fields of science were published in these statistical yearbooks $[3,4]$. The most complete information concerning the Lithuanian physicists was compiled in the "Reference Book of Physicists and Astronomers of Lithuania" [7]; there the short scientific biographies of 810 scientists (with academic degrees and/or academic titles) and other 63 distinguished physicists were presented. Data on citation of Lithuanian physicists for the period 1945-1990, collected from the "Science Citation Index", were given in [8]. The complete data on the papers, starting from 


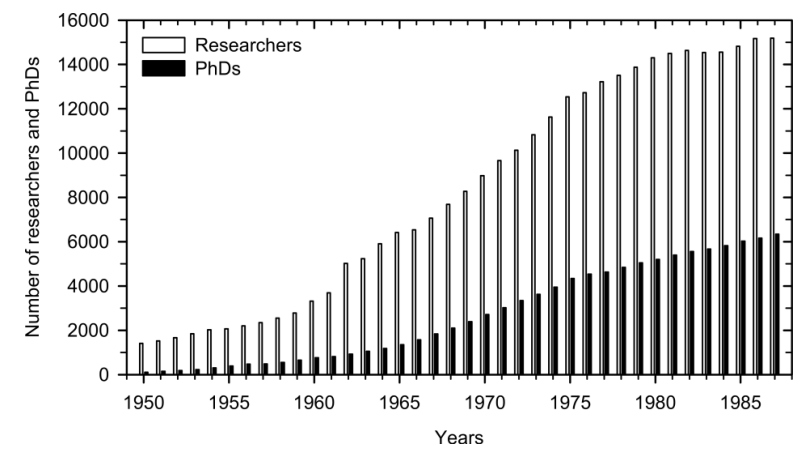

Fig. 1. Variation of the number of researchers and $\mathrm{PhDs}$ during the post-war Soviet period. Data from [1] and [2].

1990, have been included into the ISI database and citation counts are available on the Internet from the "ISI Web of Science" - the part of the "ISI Web of Knowledge" [9]. Its new part - the "Essential Science Indicators" (ESI) provides the information on the ranking of the fields of science for a particular country. Some additional material on the contribution of the Lithuanian physicists was given in [10-14]. The general trends of the development of the Lithuanian R\&D system were investigated in $[15,16]$.

The aim of this paper is to systematise and analyse the statistical data concerning the development of the Lithuanian physics in the second half of the 20th century.

\section{Results and their discussion}

Several years after the Second World War the budget funding for science in Lithuanian SSR was allocated only for the renewal of higher schools and for solving the applied science problems. A small number of scientists were engaged in pedagogical activities. However, from the beginning of the 1950s the funding for physical, technical, medical, and some ideologyrelated social fields of science increased. Their development was one of the declared goals of the Soviet authority. The extensive growth of the Lithuanian science was possible due to its foundation laid during the period of the pre-war independence. The existing relationships with the scientific and educational centres of Russia and other republics of the USSR also played a favourable role. The physicists were among the first who began the scientific investigations after the war.

Since the middle of the 1950s the total number of researchers in Lithuania has increased approximately according to a logistic law: at first almost exponentially, later - rectilinearly (Fig. 1). In the period from 1958 to 1975 (when the data on the particular fields were

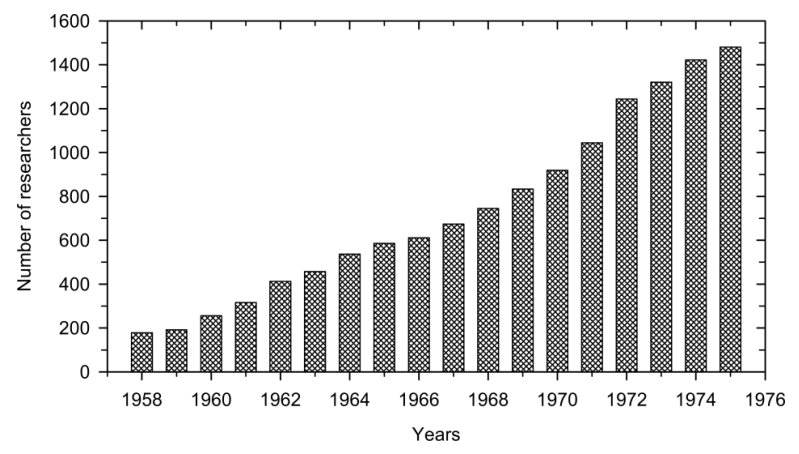

Fig. 2. Variation of the number of researchers in the field of physics and mathematics during the period when such data were published. Data from [1] and [2].

published) the number of researchers in physics and mathematics increased by 8.3 times (Fig. 2; the number of physicists amounted to about two thirds of the total), and their share in the R\&D system of Lithuania increased from $7 \%$ to $12 \%$. In 1956 the first Institute of Physics and Mathematics (IPM) was organized, in seven years its staff increased by more than seven times. In 1967 on the basis of experimental departments of IPM the Institute of Semiconductor Physics was organized, and in 1977 the IPM was divided into the Institute of Physics and Institute of Mathematics and Cybernetics. At that time mainly on the initiative of the pioneers of the contemporary physics in Lithuania P. Brazdžiūnas and A. Jucys the main directions of physics in Lithuania were selected and formed.

However, in the middle of the 1970s (about fifteen years before the disintegration of the USSR) the number of researchers, candidates of sciences (PhDs), as well as some other indicators of R\&D system showed a tendency to slow down and approach an asymptotic limit. It indicated that already then the semiclosed, bureaucratic, strictly controlled Soviet science met with serious difficulties. Physics was not an exception, but it had more reserves at its disposal (Fig. 2).

After the restoration of Lithuania's independence the scientific potential collapsed: the number of researchers diminished by more than three times in a four year period (Fig. 3; the corrected statistical data recalculated to the full-time equivalent are given). This happened due to the major social and economical changes, inflation, reduction of the state financing, the broken scientific relationships with the former USSR, and still tenuous links of the most fields of Lithuanian science with the Western science. Some researchers switched to other better paid jobs at the commercial and governmental structures. The brain drain of Lithuanian scientists to the West was not significant at first. Predominantly the technicians and researchers without 


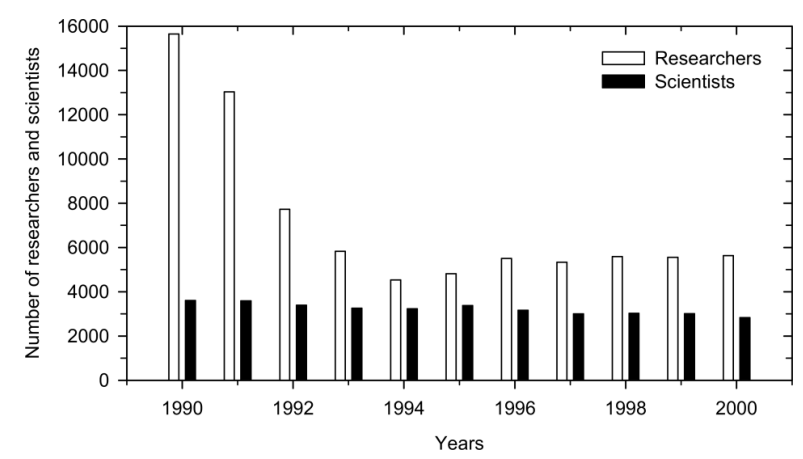

Fig. 3. Variation of the number of researchers and scientists (with academic degrees or academic titles) after the restoration of Lithuania's independence. Figure taken from [6].
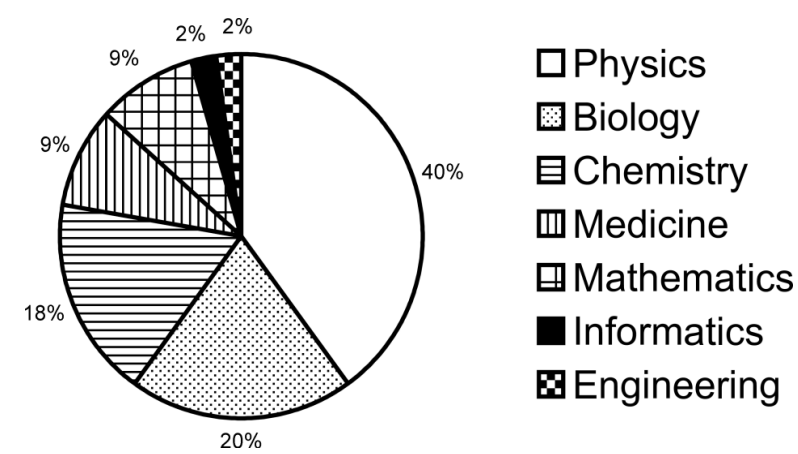

Fig. 4. Distribution of publications by Lithuanian scientists that were cited according to the "Science Citation Index" more than a hundred times in 1945-1990, among the various fields of science. Data from [8].

academic degrees changed their field of activity. Especially the staff of research laboratories at the semisecret electronic enterprises related to the military-industrial complex collapsed. On the other hand, the main potential was retained by the higher schools and the former institutes of the Lithuanian Academy of Sciences.

Physicists were prepared to these dramatic changes most of all, because even in the Soviet period they had rather solid international relations. This is supported, for example, by the data on the Lithuanian scientists cited during 1945-1990 in the journals of SCI list for a hundred and more times: the share of physicists amounted to $40 \%$ (Fig. 4).

In the transition period the physicists retained and even consolidated their leading position in the Lithuanian science: according to some indicators their contribution amounted to 40-50\%. When in 1994 the International Science Foundation allotted long-term grants to the researchers of natural sciences of the former USSR, the physicists received 52\% of those (Fig. 5). In 1997 the estimation of the activity of the state research institutes and higher schools was carried out and the corresponding detailed data were published [10].

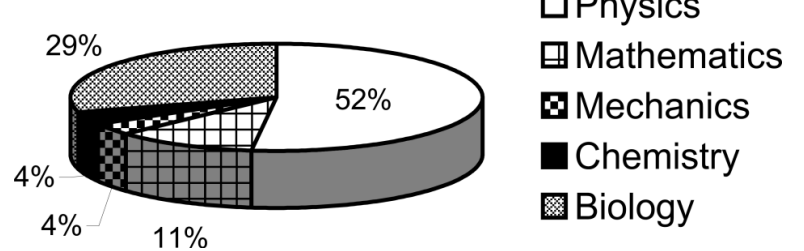

Fig. 5. Distribution of the International Science Foundation longterm research grants allotted in 1994 to support the Lithuanian scientists in transition period. Data from [12].

The papers produced by researchers from the four main physical institutions (Vilnius University, Institute of Semiconductor Physics, Institute of Physics, Institute of Theoretical Physics and Astronomy) in the journals with an impact index constituted $49 \%$ of all such publications [10]. In 1995 this contribution of all Lithuanian physicists amounted to $45 \%$ as well [15].

After the number of researchers became minimal in 1994, this indicator stabilized and even slightly increased (Fig. 3). Later it began to diminish again due to the insufficient financing of the R\&D system as well as the brain drain of the gifted students and postgraduate students to the Western countries. The latter process accelerated when Lithuania joined the European Union (unfortunately, the reliable information on the external brain-drain is not available).

However, the state funding for scientific institutions depending on the number of publications in the international journals and the necessity to receive the EC grants forced the representatives of other fields of science to make considerable efforts to integrate into the world science system. Thus, since about the middle of the 1990s the contribution of Lithuanian physicists to the publication of papers highlighted by the ISI has tended to diminish $(33.7 \%$ in $1999,25.7 \%$ in 2001 [15]). Within the period 1995-2004 the physicists still held the first place in the number of such papers but yielded to the scientists of some other fields in the citations per paper (Table 1).

The two academic degrees conferred in the Soviet period approximately correspond to the two contemporary degrees (though some inflation is noticeable). Thus, the dynamics of conferring the two academic degrees may be considered for the whole period. Hereafter we will call these Doctor of Philosophy $(\mathrm{PhD})$ and Doctor of Sciences (DSc).

Up to 1953 the physicists had been receiving a $\mathrm{PhD}$ degree not every year, in 1953-1966 every year several physicists had received this degree, and only since 1967 - fifteen to thirty per year (Fig. 6). Two minima, in 1976 and in 1994, were related with the temporary suspension of conferring the degrees: in 1975 
Table 1. Contribution of various fields of the Lithuanian science to the international science for the ten year period 1995-2004. The numbers of papers in the ISI indexed journals and citations of these papers are taken from [9].

\begin{tabular}{lrrr}
\hline Field of science & Papers & Citations & $\begin{array}{c}\text { Citations } \\
\text { per paper }\end{array}$ \\
\hline Physics & 1180 & 5726 & 4.85 \\
Chemistry & 894 & 3481 & 3.89 \\
Engineering & 490 & 1339 & 2.73 \\
Materials science & 471 & 968 & 2.06 \\
Clinical medicine & 397 & 3292 & 8.29 \\
Biology and biochemistry & 334 & 2930 & 8.77 \\
Mathematics & 308 & 397 & 1.29 \\
Plant and animal science & 231 & 806 & 3.49 \\
Space science & 131 & 508 & 3.88 \\
Molec. biology, genetics & 108 & 1604 & 14.85 \\
Geosciences & 81 & 361 & 4.46 \\
Agricultural sciences & 81 & 192 & 2.37 \\
Microbiology & 74 & 614 & 8.30 \\
Computer science & 73 & 65 & 0.89 \\
Social sciences (general) & 71 & 107 & 1.51 \\
Neuroscience and behaviour & 44 & 487 & 11.07 \\
Immunology & 41 & 445 & 10.85 \\
Pharmacology, toxicology & 40 & 186 & 4.65 \\
Psychiatry, psychology & 28 & 118 & 4.21 \\
\hline
\end{tabular}

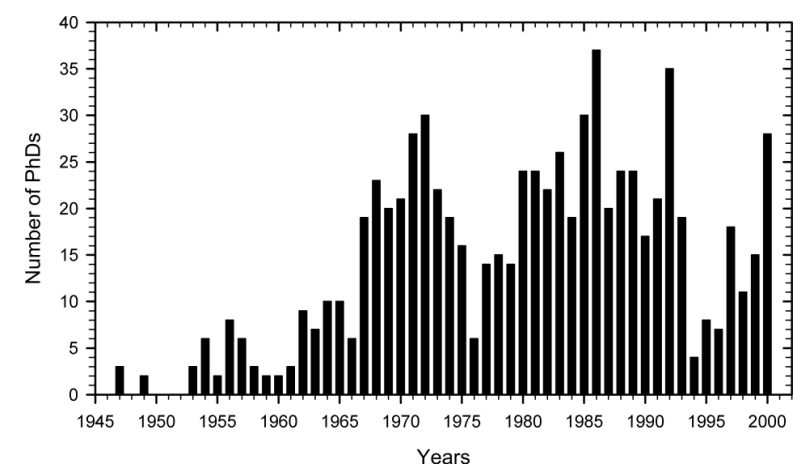

Fig. 6. Dynamics of conferring the $\mathrm{PhD}$ degree in physics. Data from [7].

the specialized councils (entitled to confer the academic degrees) underwent the reorganization, and in the independent Lithuania the new system of conferring was being arranged and implemented during more than two years (at that time some physicists received their degrees abroad).

The conferring of a $\mathrm{PhD}$ (Fig. 6) and particularly of a DSc (Fig. 7) degree did not show the tendency to slow down after the restoration of Lithuania's independence: the researchers in a position to earn a degree continued their activities. The process of conferring the degrees was stimulated by the lowered requirements, as well as by the possibility to obtain degrees in all fields of science in Lithuania. According to [7] throughout the period from 1945 to 2000 a $\mathrm{PhD}$ degree was received

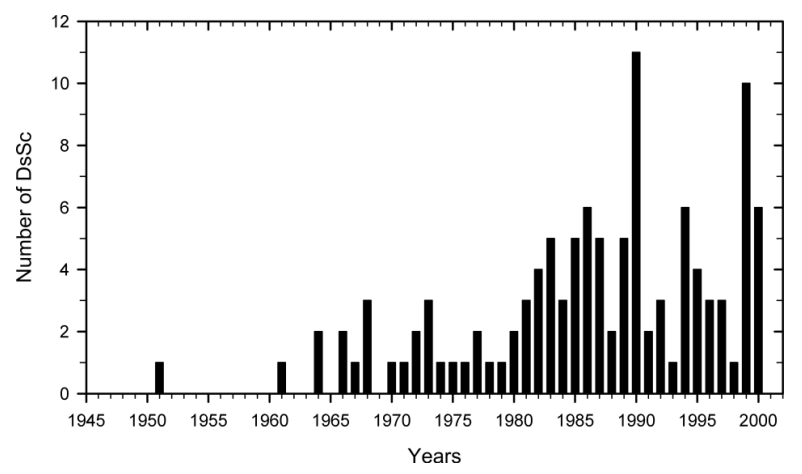

Fig. 7. Dynamics of conferring the DSc degree in physics. Data from [7].

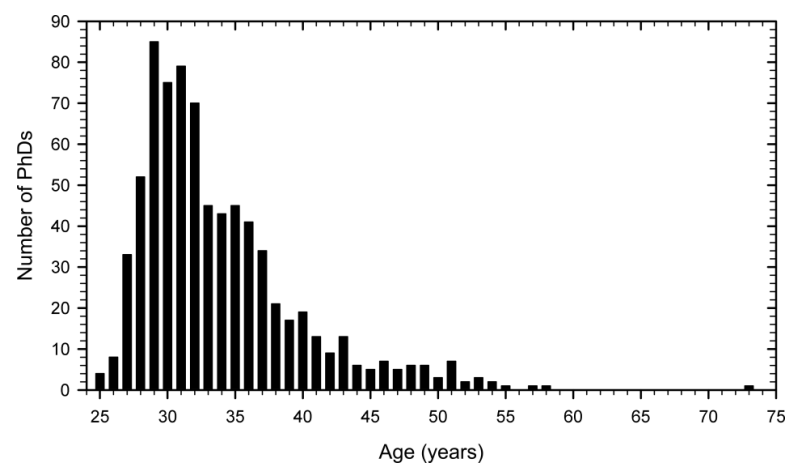

Fig. 8. Distribution of the age of physicists at the moment of receiving a PhD degree. Data from [7].

by 762 physicists and a DSc degree - by 114 (approximately one $\mathrm{DSc}$ to seven $\mathrm{PhD}$ ).

The distribution of the $\mathrm{PhDs}$ by their age at the time of receiving a degree (Fig. 8) can be approximately described by a lognormal function: a sudden increase with a maximum at the age of 29-32 (usually, the supervisor and the postgraduate student himself did their utmost to obtain the degree in a fixed time) and a slower decrease of this curve corresponding to those who did not succeed to present their thesis at the end of postgraduate studies.

The distribution of the age of physicists at the time of receiving the second academic degree has a different character (Fig. 9). In the absence of a supervisor and a definite term, the time interval spent on the more advanced work depends on various conditions: the scientific and pedagogical activity of a person, the research team working together with him, the available experimental facilities or the possibility to use them at the other scientific centres, etc. Thus, the main maximum extends between 35 and 56 years. The small second maximum corresponds probably to the rise of creativity of some scientists after the age of 50-55 [17].

The number of women who earned their $\mathrm{PhD}$ degree annually was rather small and fluctuating, but, on the 


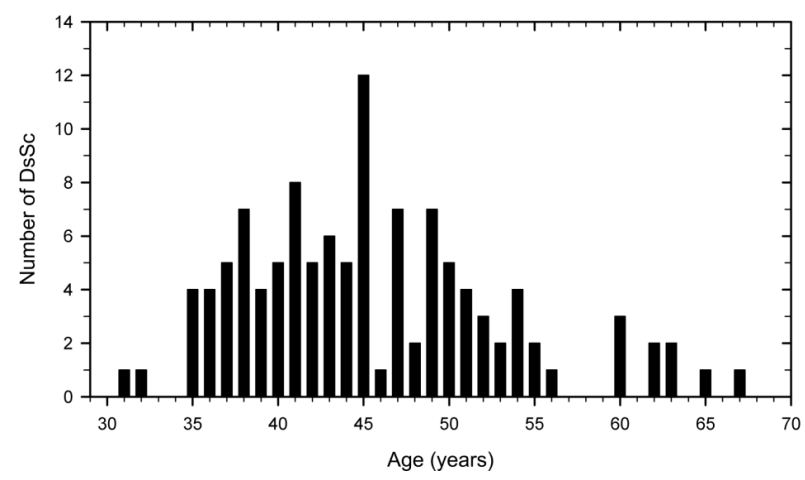

Fig. 9. Distribution of the age of physicists at the moment of receiving a DSc degree. Data from [7].

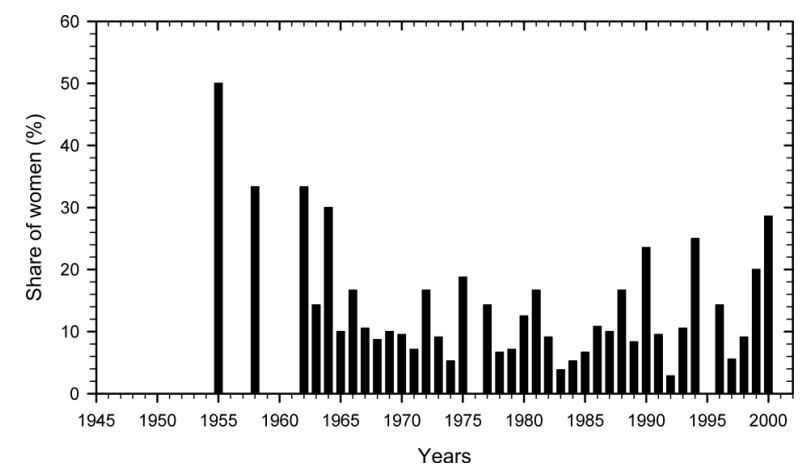

Fig. 10. Annual share (\%) of women physicists conferred a $\mathrm{PhD}$ degree. Data from [7].

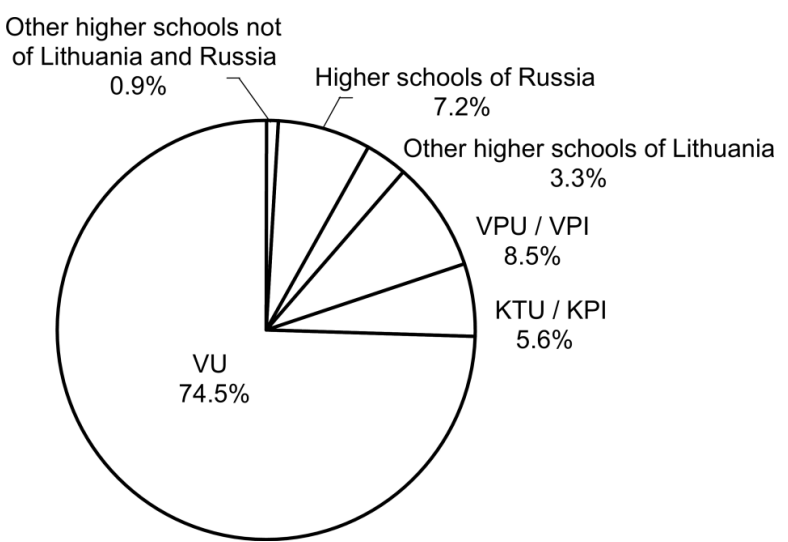

Fig. 11. Distribution of the PhDs according to the graduated higher schools. VU is Vilnius University, KTU/KPI is Kaunas University of Technology/Kaunas Polytechnical Institute, VPU/VPI is

Vilnius Pedagogical University / Vilnius Pedagogical Institute.

whole, the average value did not show a clear tendency to increase (Fig. 10). Throughout the considered period 85 women became $\mathrm{PhDs}$ (11\% of the whole number).

The role of various higher schools of Lithuania in the training of scientists in the field of physics is illustrated by Figs. 11 and 12 . The distinct leader is Vilnius University: about the three fourths of $\mathrm{PhDs}$ graduated from this university. The smaller contri-

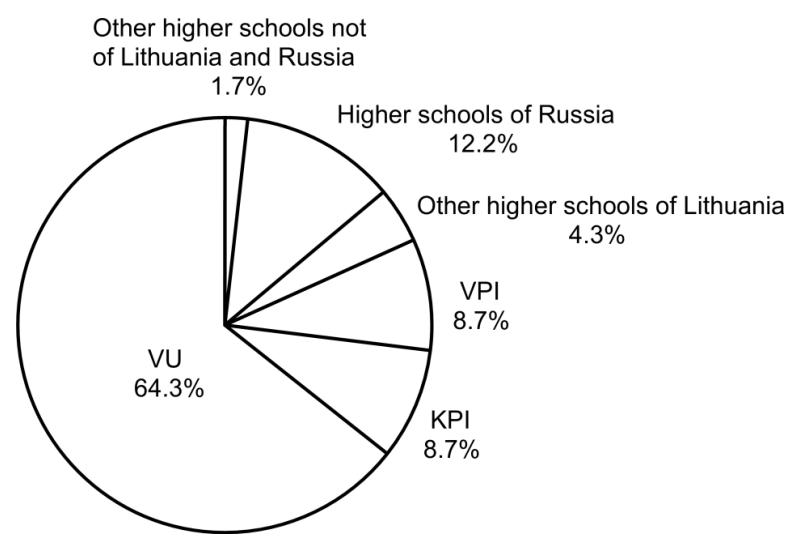

Fig. 12. Distribution of the DsSc according to the graduated higher schools. VU is Vilnius University, KPI is Kaunas Polytechnical Institute, VPI is Vilnius Pedagogical Institute.

bution was given by Kaunas University of Technology / Kaunas Polytechnical Institute, and Vilnius Pedagogical University / Vilnius Pedagogical Institute. 7\% of PhDs graduated from the higher schools of Russia, mainly of Moscow and Leningrad.

\section{Conclusions}

The second half of the 20th century was the most important period in the history of the Lithuanian physics, when its extensive growth and subsequently essential transformation occurred. The number of physicists as well as the total number of researchers in Lithuania increased approximately according to a logistic law. After the extensive growth, the development of R\&D system began to slow down and the number of researchers tended to approach an asymptotic limit much earlier than the disintegration of the USSR began. Throughout the second half of the 20th century physics was a leader in the Lithuanian science and had relatively tight international links. As a result, the physicists were better prepared for the essential changes following the restoration of Lithuania's independence, when the collapse of scientific potential took place.

In the middle of the 1990s some indicators of the contribution of physicists to the achievements of the Lithuanian science attained up to $40-50 \%$. By about 1995 the relative number of their papers in the journals highlighted by the ISI increased, but later it began to drop due to the intensive integration of the representatives of other fields of science into the international system. The conferring of a PhD and especially a DSc degree in physics did not show the sudden decrease after the restoration of Lithuania's independence. The distribution of the PhDs by their age at the moment of receiving a degree can be approximately described by 
a lognormal function. On the other hand, the corresponding distribution for the DsSc has a wider, symmetric shape. The average percentage of women who were conferred the $\mathrm{PhD}$ degree remained almost on the same level throughout the whole considered period. The distinct leader in the training of scientists has been Vilnius University.

\section{Acknowledgements}

We would like to express our gratitude to Dr E. Makariūniene for the possibility to use the electronic version of the "Reference Book of Physicists and Astronomers of Lithuania" and to Mrs K. Višnevskiene for some preliminary results obtained using this Reference book.

\section{References}

[1] Lietuvos TSR liaudies $\bar{k} k i s$, Statistikos metraštis (Statistics, Vilnius, 1957-1962, 1965-1966, 19781987) [National Economy of the Lithuanian SSR, Statistical Yearbook, in Lithuanian].

[2] Lietuvos TSR ekonomika ir kultūra, Statistikos metraštis (Statistics, Vilnius, 1963-1964, 1967-1977) [Economy and Culture of the Lithuanian SSR, Statistical Yearbook, in Lithuanian].

[3] Lietuvos statistikos metraštis (Statistics, Vilnius, 1991-2004) [Statistical Yearbook of Lithuania, in Lithuanian].

[4] Mokslo darbuotojai ir ju veikla, Statistikos biuletenis (Statistics, Vilnius, 1991-2003) [Research Activity, Statistical bulletin, in Lithuanian].

[5] V. Gontis, Lietuvoje tyrèju priskaičiuojama beveik dvigubai daugiau, negu yra iš tikrujue, Mokslo Lietuva 1 (2003) [The researchers in Lithuania are counted almost twice than it is in reality, in Lithuanian].

[6] V. Gontis, Lithuanian science in transition: Statistical analysis, Revue Baltique 16, 24-32 (2002).
[7] E. Makariūnienè and L. Klimka, Lietuvos fiziku ir astronomu squadas (Institute of Physics, Vilnius, 2001) [Reference Book of Physicists and Astronomers of Lithuania, in Lithuanian].

[8] O. Voverienè, Bibliometrija (Mokslo aidai, Vilnius, 1999) [Bibliometry, in Lithuanian].

[9] ISI Web of Knowledge, http://isi01.isiknowledge.com/.

[10] Instituciju mokslinès veiklos vertinimo išvados, Informacinis leidinys Nr. 4 (Lithuanian Centre for Quality Assessment in Higher Education, Vilnius, 1999) [Conclusions of the Estimation of Scientific Activity of Institutions, Reference Book No. 4, in Lithuanian].

[11] Doktorantūros būklès Lietuvos mokslo ir studiju institucijose studija (Science Council of Lithuania, Vilnius, 2000) [Study of the State of Postgraduate Studies in the Research and Higher Education Institutions, in Lithuanian].

[12] A. Krotkus, Tarptautinio mokslo fondo parama ilgalaikiams mokslo tyrimams, Fizikų žinios 7, 11-12 (1994) [The support of the International Science Foundation for the long-term scientific investigations, in Lithuanian].

[13] R. Karazija, Valstybiniai mokslo institutai reformų kryžkeleje, Mokslo Lietuva 19-21 (2000) [State scientific institutes at the crossroad of reforms, in Lithuanian].

[14] R. Karazija and A. Momkauskaite, Mokslinès ir visuomeninès veiklos dèsningumai, kn. Akademikas Adolfas Jucys (Lithuanian Science, Vilnius, 2004) pp. 18-34 [Regularities of the scientific and public activity, in: Academician Adolfas Jucys, in Lithuanian].

[15] J. Kristapson, H. Martinson, and J. Dagyte, Baltic $R \& D$ Systems in Transition. Experiences and Future Prospect (Zinatne, Riga, 2003).

[16] Mokslas ir tautos bei valstybès likimas, interview with K. Makariūnas, Mokslo Lietuva 17 (1999) [Science and national destiny, in Lithuanian].

[17] H. Lehman, Man's creative production rate at different ages in different countries, Scientific Monthly 78, 321326 (1954). 


\title{
LIETUVOS FIZIKOS RAIDA XX A. ANTROJE PUSĖJE: STATISTINE் ANALIZE்
}

\author{
R. Karazija ${ }^{\mathrm{a}}$, A. Momkauskaite ${ }^{\mathrm{b}}$, R. Kivilšiené ${ }^{\mathrm{b}}$ \\ ${ }^{a}$ Vilniaus pedagoginis universitetas, Vilnius, Lietuva \\ ${ }^{\mathrm{b}}$ Vilniaus universiteto Teorines fizikos ir astronomijos institutas, Vilnius, Lietuva
}

\section{Santrauka}

$\mathrm{XX}$ a. antroji pusè - svarbiausias Lietuvos fizikos plètojimo etapas, jos pagrindiniu krypčiu formavimo, integravimosi i pasaulio mokslą laikotarpis. Dar neparašyta šio laikotarpio istorija turètų remtis ne tik dokumentais, atsiminimais, bet ir statistiniais duomenimis. Šiame straipsnyje pateikiami ir analizuojami statistiniai duomenys apie Lietuvos fizikos raidą XX a. antroje puseje, jos indèli i Lietuvos ir pasaulio moksla.

Fizikos augimas Lietuvoje pokario metais prasidejjo anksčiau negu daugelio kitu mokslo šakų, ir ji tapo lydere. Maždaug iki 1975 m. mokslo darbuotojų skaičius augo beveik eksponentiškai, tačiau véliau - dèl TSRS mokslo sistemos uždarumo ir kitų trūkumu - kitimas igijo logistini pobūdị. Vis dèlto fizikai sugebejo palaikyti neblogus ryšius su Vakarų šalių mokslo centrais, tai iga- lino juos geriau pasinaudoti atsivèrusiomis po Lietuvos Nepriklausomybès atkūrimo platesnèmis tarptautinio bendradarbiavimo galimybėmis, su mažesniais nuostoliais pragyventi reformu laikotarpi. $\mathrm{XX}$ a. dešimtojo dešimtmečio pradžioje Lietuvos fiziku indèlis $\mathfrak{i}$ pasaulio mokslą pagal îvairius kiekybinius rodiklius - straipsniu skaičių moksliniuose žurnaluose su įtakos koeficientu, darbu cituojamumą, gaunamus tarptautinius grantus - sudarè net $40-50 \%$ viso Lietuvos mokslo indèlio. Pastaruoju metu gerokai išaugo chemikų, matematikų, medikų rodikliai, bet fizikai dar pirmauja pagal straipsnių, spausdinamų ISI sąrašo leidiniuose, skaičių.

Straipsnyje taip pat pateikiami ir aptariami statistiniai duomenys apie fiziku disertacijų gynimo dinamiką, amžių disertacijos gynimo metu, ìvairių aukštujų mokyklų indèlị rengiant mokslininkus, moterų mokslininkių procento kitimą ir kita. 